\title{
Recent Insights into the Implication of Nitric Oxide in Osteoblast Differentiation and Proliferation during Bone Development
}

\author{
Marta Saura ${ }^{1}$, Carlos Tarin ${ }^{2}$, and Carlos Zaragoza ${ }^{2, \star}$ \\ ${ }^{1}$ Departamento de Fisiologia, Facultad de Medicina, Universidad de Alcala, Madrid; \\ ${ }^{2}$ Fundación Centro Nacional de Investigaciones Cardiovasculares (CNIC), Madrid \\ E-mail: czaragoza@cnic.es
}

Received December 31, 2009; Revised March 3, 2010; Accepted March 10, 2010; Published April 13, 2010

Bone tissue renovation is a dynamic event in which osteoblasts and osteoclasts are responsible for the turnover between bone formation and bone resorption, respectively. During bone development, extracellular matrix remodeling is required for osteoblast differentiation and the process is largely mediated by the proteolytic activity of extracellular matrix metalloproteinases (MMPs), which play a fundamental role in osteoblast migration, unmineralized matrix degradation, and cell invasion. The recent advances towards investigation in osteogenesis have provided significant information about the transcriptional regulation of several genes, including MMPs, by the expression of crucial transcription factors like NFAT, ATF4, osterix, TAZ, and Cbfa-1-responsive elements. Evidence from gene knock-out studies have shown that bone formation is, at least in part, mediated by nitric oxide (NO), since mice deficient in endothelial nitric oxide synthase (eNOS) and mice deficient in the eNOS downstream effector (cGMP)-dependent protein kinase (PKG) show bone abnormalities, while inducible NOS (iNOS) null mice also show imbalances in bone osteogenesis and abnormalities in bone healing. Recently, in vitro data showed that $\mathrm{Cbfa}-1$ and the MAPK pathways were crucial for osteoblastic cell differentiation, and NO was found to play a significant role. This article sheds light on some of the mechanisms that may influence NO-mediated actions in bone development.

KEYWORDS: nitric oxide, nitric oxide synthase, matrix metalloproteinase, MMP-13, osteoblast, bone, chondrocyte, runx2, Cbfa1

\section{OSTEOBLAST DIFFERENTIATION DURING OSTEOGENESIS}

Osteogenesis is a complex process that involves epithelial-mesenchymal interaction, condensation, and final differentiation. Flat bones are developed by intramembranous ossification, whereas long bones are developed by endochondral ossification[1]. Intramembranous ossification results from differentiation of mesenchymal precursors into osteoblasts, whereas endochondral ossification starts during embryogenesis when mesenchymal cells condense and differentiate into chondrocytes[2]. During chondrocyte differentiation, the cartilage extracellular matrix $(\mathrm{ECM})$ is partially degraded and colonized by 
osteoblasts, osteoclasts, and blood vessels, and nitric oxide (NO) has been implicated in this process[3,4,5,6].

Signals triggering osteoblast differentiation are mediated by the expression and activation of cellspecific transcription factors, including core binding factor a-1 (Cbfa-1)[7,8], osterix[9,10], $\beta$-catenin[11], ATF4[12,13], and NFATc1[14,15]. The osteoblastic program comprises the transition from mesenchymal stem cells to preosteoblasts, immature osteoblasts, and mature osteoblasts. Mature osteoblasts express high levels of ECM-degrading enzymes and are embedded into the bone matrix to differentiate into osteocytes. Transcription factor Cbfa-1 was found responsible for mesenchymal cell differentiation into preosteoblastic cells[16,17,18,19], which in association with the downstream osterix and ATF4 transcription factors, in combination with AP1, C/EBPs, PPARs, and helix-loop-helix proteins, will allow mature osteoblasts to become osteocytes[20,21]. Investigation towards Cbfa-1 is today focused in finding upstream effectors that may be considered candidate markers for the treatment and prevention of bonerelated diseases[22,23]. As depicted below, $\mathrm{NO}$ was found to regulate Cbfa-1-mediated expression of MMP-13 in osteoblasts transcriptionally and post-transcriptionally[24].

\section{MATRIX METALLOPROTEINASES (MMPS) AND OSTEOBLASTS: ROLE OF MMP- 13 IN BONE FORMATION}

Bone development requires a complex remodeling of the ECM, including cartilage degradation by cleavage of fibrillar collagens. ECM remodeling is related to MMP-13-dependent collagenolytic activity, which is mainly produced by osteoblasts and hypertrophic chondrocytes[25], and is crucial for osteoblast migration, endothelial cell invasion, and for vessel formation in the expanded hypertrophic cartilage[25,26,27,28,29,30,31]. Besides MMP-13, invading osteoblasts also express lower levels of collagenase MMP-8 (collagenase-2), membrane type MMP-14 (membrane type-1-MMP), and gelatinases MMP-2, MMP-9, and aggrecan-degrading ADAMTS1, ADAMTS4, and ADAMTS5[32,33,34,35,36].

The relevance of MMP-13 in bone formation came from studies in knock-out mice, finding that lack of MMP-13 resulted in altered endochondral bone development, with abnormal skeletal growth plate development[31]. Furthermore, in humans, a mis-sense mutation of MMP-13 is the leading source of the Missouri variant skeletal spondyloepimetaphyseal dysplasia $\left(\mathrm{SEMD}_{\mathrm{MO}}\right)$, which results in the secretion of an inactive and smaller MMP-13 fragment[37].

The mechanisms leading to MMP expression, including MMP-13, are largely dependent on the activation of osteogenic differentiation-specific transcription factors, including Cbfa-1[28,38,39]. In particular, expression, transactivation, and binding of Cbfa-1 to the corresponding OSE-2 binding elements located in the regulatory region of several osteoblastic genes have been identified as essential steps in osteoblast differentiation. This process is crucial for endochondral bone formation during cartilage remodeling by inducing the expression of several genes in which Cbfa-1-mediated MMP expression promotes endothelial cell migration during vascular invasion, osteoblast migration, and differentiation in developing bones[1,40,41,42,43,44].

\section{BIOLOGICAL EFFECTS OF NO}

More than 2 decades ago, the discovery of NO was revolutionary considering the nature of this compound. A huge number of different roles were assigned to NO, but how NO exerts some of its effects is today one of the main challenges in biomedicine. NO is a gas-reactive nitrogen species (RNS), which is produced during the conversion of the amino acid L-arginine into L-cytruline. Since its discovery, NO was found to be involved in a wide number of pathophysiological events in living organisms [45], including plants[46]. In the cardiovascular system, NO derived from endothelial cells is a vascular tone keeper in the vessel wall, it is a proangiogenic factor, and it inhibits adhesion of immune cells and platelets[47]. In the central nervous system, NO exerts neurotransmission effects[48], whereas in the 
immune system, proinflammatory cytokines induce the production of high levels of NO by immune cells, participating as a second messenger on many different inflammatory events, as well in the defense against different types of pathogens including bacteria and viruses[49,50,51,52].

Nitric oxide synthase (NOS) is the enzyme responsible for producing NO, and three isoforms have been reported. Endothelial NOS (eNOS, NOS3) and neuronal NOS (nNOS, NOS1) are both constitutively expressed and calcium-dependent enzymes, producing NO at low concentration. On the other hand, inducible NOS (iNOS, NOS2) is only expressed in response to different stimuli associated with inflammatory responses and produces $\mathrm{NO}$ at a high concentration in a calcium-independent manner[53]. Both eNOS and iNOS are widely expressed in bone marrow stromal cells, osteoblasts, osteocytes, and osteoclasts, whereas nNOS expression is restricted to bone lining cells and osteoclasts.

\section{NITRIC OXIDE AND OSTEOBLAST DIFFERENTIATION}

The implication of NO in bone development, bone healing, and bone resorption has been documented[54,55,56,57]. Mice lacking eNOS exhibit profound abnormalities in bone formation, and osteoblasts isolated from calvarial explants show significant delay in proliferation, differentiation, and a reduction on Cbfa-1 levels, the main checkpoint in osteoblast differentiation, pointing to this transcription factor as the main target for the actions of eNOS and suggesting an effect of NO on Cbfa-1 expression[58,59]. To this regard, recent studies have demonstrated the effect of NO on Cbfa-1 expression in fetal calvarial osteoblasts and dural cells[60]. Interestingly, the levels of MMP-13 (transcriptionally regulated by $\mathrm{Cbfa}-1$ ) found in endothelial cells isolated from the same mice were also significantly reduced[61] and, as mentioned before, MMP-13 null mice have also shown bone abnormalities during endochondral ossification[31] and fracture healing[62]. Incubation of eNOS null osteoblastic cells with NO donors significantly recovered the levels of Cbfa-1 found in wild-type osteoblasts and were correlated with a boost in cellular proliferation and differentiation[59,63].

The use of iNOS null mice revealed no significant alterations in bone development, as compared to the phenotype exhibited by eNOS-deficient animals. However, and as discussed below, significant iNOS expression is induced during the process of osteoblast differentiation[24]. Even when iNOS and eNOS are both involved in the production of NO, the underlying differences between both isoforms may help us to understand both phenotypes. Whereas the eNOS isoform is constitutively expressed, thus constantly producing low levels of NO, the iNOS isoform remains inhibited until certain stimuli, mostly proinflammatory, induce the expression of the enzyme and only at that time high levels of NO are produced. To this regard, the relevance of iNOS was related to processes in which proinflammatory stimuli play a pivotal role, and such is the case of fracture healing in which a lack of iNOS was found associated with impaired healing in mice[64,65].

The third isoform of NOS, neuronal NOS (nNOS), is also constitutively expressed at very low levels in bone cells. However, a possible role for nNOS in bone turnover was suggested[66].

\section{iNOS AND OSTEOBLAST DIFFERENTIATION}

The contribution of iNOS in osteoblast differentiation is apparently dual[54]. Osteoblast differentiation induces the expression of iNOS and MMP-13 in a time-dependent manner. NO-mediated MMP-13 expression is transcriptionally regulated in osteoblasts by Cbfa-1 through the cGMP/PKG pathway, and the levels of Cbfa-1 are significantly reduced in mouse embryos lacking iNOS. These observations, together with the fact that pharmacological inhibition of iNOS decreases Cbfa-1 nuclear translocation, suggest that NO is an upstream effector of Cbfa-1-mediated gene expression in osteoblasts[24].

Cbfa- 1 activation is mediated by phosphorylation at different residues[67,68,69,70,71,72,73,74,75], and MAPK extracellular signal-regulated protein kinase (ERK), p38, and protein kinase A (PKA) were found to phosphorylate Cbfa-1 under different conditions[73,74,75,76]. However, the kinase(s) 
responsible for NO-mediated Cbfa-1 activation has not been fully characterized in vivo, although in vitro phosphorylation studies revealed PKG-mediated phosphorylation of Cbfa-1 in a cGMP-dependent manner, whereas the precise phosphorylation site in the primary structure still remains to be elucidated[24]. Supporting this possibility, PKG-deficient mice also exhibit bone abnormalities[77,78].

As previously mentioned, the dual role of NO was revealed since, in response to proinflammatory cytokines, high amounts of $\mathrm{NO}$ are produced and have a significant inhibitory effect in osteoblast proliferation and differentiation, thus suppressing bone formation, as detected during the course of experimental inflammatory bone diseases[79,80]. The inhibitory effect of NO was associated with increased apoptosis $[81,82,83,84]$, but in addition to the expression of collagenolytic proteases, leading to further destruction of the tissue[85].

\section{NITRIC OXIDE AND OSTEOBLAST PROLIFERATION}

Besides the effect on osteoblast differentiation, NO is considered a double-edged sword, since it is also involved in osteoblast proliferation and apoptosis simultaneously. NO was found to induce proliferation in association with mitochondrial-dependent mechanisms[86] and antagonizing with reactive oxygen species[87]. However, NO induces osteoblastic cell death by different ways, including caspase-3 activation[83], antiapoptotic $\mathrm{Bcl}_{2}$ and $\mathrm{Bcl}_{X} \mathrm{~L}$ down-regulation[84], and proapoptotic Bax upregulation[88]. This apparent discrepancy may be related to the concentration of NO and to the speed at which NO is released. Low doses of NO were associated with cell proliferation, while NO-mediated apoptosis was frequently associated with a rapid release of high concentrations of NO, which are also related to different pathological conditions.

\section{NITRIC OXIDE AND DISEASE}

iNOS has been associated with many pathological disorders, including inflammatory and autoimmune diseases. Proinflammatory cytokines and microorganism-derived degradation products stimulate the activation of different transcription factors involved in the transcriptional regulation of several genes, including iNOS. To this regard, rheumatoid arthritis (RA) and osteoarthritis (OA) are both welldocumented examples in which high levels of NO contribute to tissue destruction by increasing MMP expression[89,90,91], and up-regulation of p53[92] and Akt phosphorylation[93]-mediated apoptosis[94]. Further destruction of the tissue is associated with enhanced production of NO in peripheral blood mononuclear cells[95] and NO-mediated abnormal T-cell accumulation in the joints of patients with RA[96,97].

A number of polymorphisms in the iNOS and eNOS genes have been identified and associated with different vascular, autoimmune, and infectious diseases. Direct association between the iNOS polymorphism ([CCTTT $]_{\mathrm{n}}$, a microsatellite repeat in the promoter region) with RA were evaluated in different human populations, suggesting increased susceptibility[98]. However, in a different cohort study, no association between this and other iNOS polymorphisms were found to be significant[99]. In the case of eNOS, results were also controversial, since some studies pointed to the existence of an association between polymorphism T-786C (a single-base substitution in the promoter region) in a Spanish population and a polymorphism in the eNOS intron 4a/b VNTR (a 27-base-pair tandem repeat) in Greek and Brazilian populations to RA[100,101]. Other studies, by contrast, did not show significant differences[102]. In consequence, the relevance of iNOS and eNOS polymorphisms should be considered restricted to specific groups of population. 


\section{CONCLUSIONS}

The relevance of NO in bone development has been extensively explored. Recent advances have provided molecular insights about the precise role of $\mathrm{NO}$ at the transcriptional and post-transcriptional levels. Future work should help to shed light about the pathophysiological relevance of controlling the bioavailability of this important vasoactive factor for the implication in future treatments of animal and human bone diseases.

\section{REFERENCES}

1. Mackie, E.J., Ahmed, Y.A., Tatarczuch, L., Chen, K.S., and Mirams, M. (2008) Endochondral ossification: how cartilage is converted into bone in the developing skeleton. Int. J. Biochem. Cell Biol. 40, 46-62.

2. Karsenty, G. (2001) Minireview: transcriptional control of osteoblast differentiation. Endocrinology 142, $2731-2733$.

3. Yu, H., Wooley, P.H., and Yang, S.Y. (2009) Biocompatibility of poly-epsilon-caprolactone-hydroxyapatite composite on mouse bone marrow-derived osteoblasts and endothelial cells. J. Orthop. Surg. Res. 4, 5.

4. Wang, F.S., Kuo, Y.R., Wang, C.J., Yang, K.D., Chang, P.R., Huang, Y.T., Huang, H.C., Sun, Y.C., Yang, Y.J., and Chen, Y.J. (2004) Nitric oxide mediates ultrasound-induced hypoxia-inducible factor-1alpha activation and vascular endothelial growth factor-A expression in human osteoblasts. Bone 35, 114-123.

5. Komatsu, D.E. and Hadjiargyrou, M. (2004) Activation of the transcription factor HIF-1 and its target genes, VEGF, HO-1, iNOS, during fracture repair. Bone 34, 680-688.

6. Wang, F.S., Wang, C.J., Chen, Y.J., Chang, P.R., Huang, Y.T., Sun, Y.C., Huang, H.C., Yang, Y.J., and Yang, K.D. (2004) Ras induction of superoxide activates ERK-dependent angiogenic transcription factor HIF-1alpha and VEGFA expression in shock wave-stimulated osteoblasts. J. Biol. Chem. 279, 10331-10337.

7. Komori, T., Yagi, H., Nomura, S., Yamaguchi, A., Sasaki, K., Deguchi, K., Shimizu, Y., Bronson, R.T., Gao, Y.H., Inada, M., Sato, M., Okamoto, R., Kitamura, Y., Yoshiki, S., and Kishimoto, T. (1997) Targeted disruption of Cbfa1 results in a complete lack of bone formation owing to maturational arrest of osteoblasts. Cell 89, 755-764.

8. Otto, F., Thornell, A.P., Crompton, T., Denzel, A., Gilmour, K.C., Rosewell, I.R., Stamp, G.W., Beddington, R.S., Mundlos, S., Olsen, B.R., Selby, P.B., and Owen, M.J. (1997) Cbfa1, a candidate gene for cleidocranial dysplasia syndrome, is essential for osteoblast differentiation and bone development. Cell 89, 765-771.

9. Kaback, L.A., Soung do, Y., Naik, A., Smith, N., Schwarz, E.M., O'Keefe, R.J., and Drissi, H. (2008) Osterix/Sp7 regulates mesenchymal stem cell mediated endochondral ossification. J. Cell. Physiol. 214, 173-182.

10. Fu, H., Doll, B., McNelis, T., and Hollinger, J.O. (2007) Osteoblast differentiation in vitro and in vivo promoted by Osterix. J. Biomed. Mater. Res. 83, 770-778.

11. Holmen, S.L., Zylstra, C.R., Mukherjee, A., Sigler, R.E., Faugere, M.C., Bouxsein, M.L., Deng, L., Clemens, T.L., and Williams, B.O. (2005) Essential role of beta-catenin in postnatal bone acquisition. J. Biol. Chem. 280, 2116221168.

12. Yu, V.W., Akhouayri, O., and St-Arnaud, R. (2009) FIAT is co-expressed with its dimerization target ATF4 in early osteoblasts, but not in osteocytes. Gene Expr. Patterns 9, 335-340.

13. Matsuguchi, T., Chiba, N., Bandow, K., Kakimoto, K., Masuda, A., and Ohnishi, T. (2009) JNK activity is essential for Atf4 expression and late-stage osteoblast differentiation. J. Bone Miner. Res. 24, 398-410.

14. Choo, M.K., Yeo, H., and Zayzafoon, M. (2009) NFATc1 mediates HDAC-dependent transcriptional repression of osteocalcin expression during osteoblast differentiation. Bone 45, 579-589.

15. Zayzafoon, M. (2005) Inhibition of NFAT increases osteoblast differentiation by increasing Fra-2 expression. $J$. Musculoskelet. Neuronal Interact. 5, 347.

16. Zambotti, A., Makhluf, H., Shen, J., and Ducy, P. (2002) Characterization of an osteoblast-specific enhancer element in the CBFA1 gene. J. Biol. Chem. 277, 41497-41506.

17. Takeda, S., Bonnamy, J.P., Owen, M.J., Ducy, P., and Karsenty, G. (2001) Continuous expression of Cbfa1 in nonhypertrophic chondrocytes uncovers its ability to induce hypertrophic chondrocyte differentiation and partially rescues Cbfa1-deficient mice. Genes Dev. 15, 467-481.

18. Ducy, P. (2000) Cbfa1: a molecular switch in osteoblast biology. Dev. Dyn. 219, 461-471.

19. Ducy, P., Zhang, R., Geoffroy, V., Ridall, A.L., and Karsenty, G. (1997) Osf2/Cbfa1: a transcriptional activator of osteoblast differentiation. Cell 89, 747-754.

20. Komori, T. (2006) Regulation of osteoblast differentiation by transcription factors. J. Cell. Biochem. 99, 1233-1239.

21. Marie, P.J. (2008) Transcription factors controlling osteoblastogenesis. Arch. Biochem. Biophys. 473, 98-105.

22. Wu, S., Kawahara, Y., Manabe, T., Ogawa, K., Matsumoto, M., Sasaki, A., and Yuge, L. (2009) Low-intensity pulsed ultrasound accelerates osteoblast differentiation and promotes bone formation in an osteoporosis rat model. Pathobiology 76, 99-107.

23. Wimalawansa, S.J. (2007) Rationale for using nitric oxide donor therapy for prevention of bone loss and treatment of osteoporosis in humans. Ann. N. Y. Acad. Sci. 1117, 283-297. 
24. Zaragoza, C., Lopez-Rivera, E., Garcia-Rama, C., Saura, M., Martinez-Ruiz, A., Lizarbe, T.R., Martin-de-Lara, F., and Lamas, S. (2006) Cbfa-1 mediates nitric oxide regulation of MMP-13 in osteoblasts. J. Cell Sci. 119, 1896-1902. Tuckermann, J.P., Pittois, K., Partridge, N.C., Merregaert, J., and Angel, P. (2000) Collagenase-3 (MMP-13) and integral membrane protein 2a (Itm2a) are marker genes of chondrogenic/osteoblastic cells in bone formation: sequential temporal, and spatial expression of Itm2a, alkaline phosphatase, MMP-13, and osteocalcin in the mouse. $J$. Bone Miner. Res. 15, 1257-1265.

26. Hayami, T., Kapila, Y.L., and Kapila, S. (2008) MMP-1 (collagenase-1) and MMP-13 (collagenase-3) differentially regulate markers of osteoblastic differentiation in osteogenic cells. Matrix Biol. 27, 682-692.

27. Varga, F., Rumpler, M., Spitzer, S., Karlic, H., and Klaushofer, K. (2009) Osteocalcin attenuates T3- and increases vitamin D3-induced expression of MMP-13 in mouse osteoblasts. Endocr. J. 56, 441-450.

28. Selvamurugan, N., Shimizu, E., Lee, M., Liu, T., Li, H., and Partridge, N.C. (2009) Identification and characterization of Runx2 phosphorylation sites involved in matrix metalloproteinase-13 promoter activation. FEBS Lett. 583, 11411146.

Fratzl-Zelman, N., Glantschnig, H., Rumpler, M., Nader, A., Ellinger, A., and Varga, F. (2003) The expression of matrix metalloproteinase-13 and osteocalcin in mouse osteoblasts is related to osteoblastic differentiation and is modulated by 1,25-dihydroxyvitamin D3 and thyroid hormones. Cell Biol. Int. 27, 459-468.

30. Himeno, M., Enomoto, H., Liu, W., Ishizeki, K., Nomura, S., Kitamura, Y., and Komori, T. (2002) Impaired vascular invasion of Cbfa1-deficient cartilage engrafted in the spleen. J. Bone Miner. Res. 17, 1297-1305.

31. Stickens, D., Behonick, D.J., Ortega, N., Heyer, B., Hartenstein, B., Yu, Y., Fosang, A.J., Schorpp-Kistner, M., Angel, P., and Werb, Z. (2004) Altered endochondral bone development in matrix metalloproteinase 13-deficient mice. Development 131, 5883-5895.

32. Mizutani, A., Sugiyama, I., Kuno, E., Matsunaga, S., and Tsukagoshi, N. (2001) Expression of matrix metalloproteinases during ascorbate-induced differentiation of osteoblastic MC3T3-E1 cells. J. Bone Miner. Res. 16, 2043-2049.

33. Filanti, C., Dickson, G.R., Di Martino, D., Ulivi, V., Sanguineti, C., Romano, P., Palermo, C., and Manduca, P. (2000) The expression of metalloproteinase-2, -9, and -14 and of tissue inhibitors-1 and -2 is developmentally modulated during osteogenesis in vitro, the mature osteoblastic phenotype expressing metalloproteinase-14. J. Bone Miner. Res. 15, 2154-2168.

34. Manduca, P., Castagnino, A., Lombardini, D., Marchisio, S., Soldano, S., Ulivi, V., Zanotti, S., Garbi, C., Ferrari, N., and Palmieri, D. (2009) Role of MT1-MMP in the osteogenic differentiation. Bone 44, 251-265.

35. Sone, S., Nakamura, M., Maruya, Y., Takahashi, I., Mizoguchi, I., Mayanagi, H., and Sasano, Y. (2005) Expression of versican and ADAMTS during rat tooth eruption. J. Mol. Histol. 36, 281-288.

36. Botter, S.M., Glasson, S.S., Hopkins, B., Clockaerts, S., Weinans, H., van Leeuwen, J.P., and van Osch, G.J. (2009) ADAMTS5-/- mice have less subchondral bone changes after induction of osteoarthritis through surgical instability: implications for a link between cartilage and subchondral bone changes. Osteoarthritis Cartilage 17, 636-645.

37. Kennedy, A.M., Inada, M., Krane, S.M., Christie, P.T., Harding, B., Lopez-Otin, C., Sanchez, L.M., Pannett, A.A., Dearlove, A., Hartley, C., Byrne, M.H., Reed, A.A., Nesbit, M.A., Whyte, M.P., and Thakker, R.V. (2005) MMP13 mutation causes spondyloepimetaphyseal dysplasia, Missouri type (SEMD(MO). J. Clin. Invest. 115, 2832-2842.

38. Komori, T. (2010) Regulation of bone development and extracellular matrix protein genes by RUNX2. Cell Tissue Res. 339, 189-195.

39. Hess, J., Porte, D., Munz, C., and Angel, P. (2001) AP-1 and Cbfa/runt physically interact and regulate parathyroid hormone-dependent MMP13 expression in osteoblasts through a new osteoblast-specific element 2/AP-1 composite element. J. Biol. Chem. 276, 20029-20038.

40. Franceschi, R.T., Ge, C., Xiao, G., Roca, H., and Jiang, D. (2009) Transcriptional regulation of osteoblasts. Cells Tissues Organs 189, 144-152.

41. Franceschi, R.T., Ge, C., Xiao, G., Roca, H., and Jiang, D. (2007) Transcriptional regulation of osteoblasts. Ann. N. Y. Acad. Sci. 1116, 196-207.

42. Komori, T. (2008) Regulation of bone development and maintenance by Runx2. Front. Biosci. 13, 898-903.

43. Lian, J.B., and Stein, G.S. (2003) Runx2/Cbfa1: a multifunctional regulator of bone formation. Curr. Pharm. Des. 9, 2677-2685.

44. Franceschi, R.T., Xiao, G., Jiang, D., Gopalakrishnan, R., Yang, S., and Reith, E. (2003) Multiple signaling pathways converge on the Cbfa1/Runx2 transcription factor to regulate osteoblast differentiation. Connect. Tissue Res. 44(Suppl 1), 109-116.

45. Hobbs, A.J., Higgs, A., and Moncada, S. (1999) Inhibition of nitric oxide synthase as a potential therapeutic target. Annu. Rev. Pharmacol. Toxicol. 39, 191-220.

46. Corpas, F.J., Chaki, M., Leterrier, M., and Barroso, J.B. (2009) Protein tyrosine nitration: a new challenge in plants. Plant Signal. Behav. 4, 920-923.

47. Ignarro, L.J. (2002) Nitric oxide as a unique signaling molecule in the vascular system: a historical overview. $J$. Physiol. Pharmacol. 53, 503-514.

48. Jaffrey, S.R. and Snyder, S.H. (1995) Nitric oxide: a neural messenger. Annu. Rev. Cell Dev. Biol. 11, $417-440$.

49. Zaragoza, C., Ocampo, C.J., Saura, M., McMillan, A., and Lowenstein, C.J. (1997) Nitric oxide inhibition of coxsackievirus replication in vitro. J. Clin. Invest. 100, 1760-1767. 
50. Zaragoza, C., Ocampo, C., Saura, M., Leppo, M., Wei, X.Q., Quick, R., Moncada, S., Liew, F.Y., and Lowenstein, C.J. (1998) The role of inducible nitric oxide synthase in the host response to Coxsackievirus myocarditis. Proc. Natl. Acad. Sci. U. S. A. 95, 2469-2474.

51. Saura, M., Zaragoza, C., McMillan, A., Quick, R.A., Hohenadl, C., Lowenstein, J.M., and Lowenstein, C.J. (1999) An antiviral mechanism of nitric oxide: inhibition of a viral protease. Immunity 10, 21-28.

52. Nathan, C.F. and Hibbs, J.B., Jr. (1991) Role of nitric oxide synthesis in macrophage antimicrobial activity. Curr. Opin. Immunol. 3, 65-70.

53. Hattori, R., Sase, K., Eizawa, H., Kosuga, K., Aoyama, T., Inoue, R., Sasayama, S., Kawai, C., Yui, Y., Miyahara, K., et al. (1994) Structure and function of nitric oxide synthases. Int. J. Cardiol. 47, S71-75.

54. van't Hof, R.J. and Ralston, S.H. (2001) Nitric oxide and bone. Immunology 103, 255-261.

55. Chow, J.W. (2000) Role of nitric oxide and prostaglandins in the bone formation response to mechanical loading. Exerc. Sport Sci. Res. 28, 185-188.

56. Collin-Osdoby, P., Nickols, G.A., and Osdoby, P. (1995) Bone cell function, regulation, and communication: a role for nitric oxide. J. Cell. Biochem. 57, 399-408.

57. Teixeira, C.C., Agoston, H., and Beier, F. (2008) Nitric oxide, C-type natriuretic peptide and cGMP as regulators of endochondral ossification. Dev. Biol. 319, 171-178.

58. Armour, K.E., Armour, K.J., Gallagher, M.E., Godecke, A., Helfrich, M.H., Reid, D.M., and Ralston, S.H. (2001) Defective bone formation and anabolic response to exogenous estrogen in mice with targeted disruption of endothelial nitric oxide synthase. Endocrinology 142, 760-766.

59. Aguirre, J., Buttery, L., O'Shaughnessy, M., Afzal, F., Fernandez de Marticorena, I., Hukkanen, M., Huang, P., MacIntyre, I., and Polak, J. (2001) Endothelial nitric oxide synthase gene-deficient mice demonstrate marked retardation in postnatal bone formation, reduced bone volume, and defects in osteoblast maturation and activity. Am. J. Pathol. 158, 247-257.

60. Lin, I.C., Smartt, J.M., Jr., Nah, H.D., Ischiropoulos, H., and Kirschner, R.E. (2008) Nitric oxide stimulates proliferation and differentiation of fetal calvarial osteoblasts and dural cells. Plast. Reconstr. Surg. 121, 1554-1566; discussion 1567-1559.

61. Lopez-Rivera, E., Lizarbe, T.R., Martinez-Moreno, M., Lopez-Novoa, J.M., Rodriguez-Barbero, A., Rodrigo, J., Fernandez, A.P., Alvarez-Barrientos, A., Lamas, S., and Zaragoza, C. (2005) Matrix metalloproteinase 13 mediates nitric oxide activation of endothelial cell migration. Proc. Natl. Acad. Sci. U. S. A. 102, 3685-3690.

62. Kosaki, N., Takaishi, H., Kamekura, S., Kimura, T., Okada, Y., Minqi, L., Amizuka, N., Chung, U.I., Nakamura, K., Kawaguchi, H., Toyama, Y., and D'Armiento, J. (2007) Impaired bone fracture healing in matrix metalloproteinase13 deficient mice. Biochem. Biophys. Res. Commun. 354, 846-851.

63. Afzal, F., Polak, J., and Buttery, L. (2004) Endothelial nitric oxide synthase in the control of osteoblastic mineralizing activity and bone integrity. J. Pathol. 202, 503-510.

64. Baldik, Y., Diwan, A.D., Appleyard, R.C., Fang, Z.M., Wang, Y., and Murrell, G.A. (2005) Deletion of iNOS gene impairs mouse fracture healing. Bone 37, 32-36.

65. Arasapam, G., Scherer, M., Cool, J.C., Foster, B.K., and Xian, C.J. (2006) Roles of COX-2 and iNOS in the bony repair of the injured growth plate cartilage. J. Cell. Biochem. 99, 450-461.

66. van't Hof, R.J., Macphee, J., Libouban, H., Helfrich, M.H., and Ralston, S.H. (2004) Regulation of bone mass and bone turnover by neuronal nitric oxide synthase. Endocrinology 145, 5068-5074.

67. Gordon, J.A., Hunter, G.K., and Goldberg, H.A. (2009) Activation of the mitogen-activated protein kinase pathway by bone sialoprotein regulates osteoblast differentiation. Cells Tissues Organs 189, 138-143.

68. Lee, H.W., Suh, J.H., Kim, H.N., Kim, A.Y., Park, S.Y., Shin, C.S., Choi, J.Y., and Kim, J.B. (2008) Berberine promotes osteoblast differentiation by Runx2 activation with p38 MAPK. J. Bone Miner. Res. 23, 1227-1237.

69. Kanno, T., Takahashi, T., Tsujisawa, T., Ariyoshi, W., and Nishihara, T. (2007) Mechanical stress-mediated Runx2 activation is dependent on Ras/ERK1/2 MAPK signaling in osteoblasts. J. Cell. Biochem. 101, 1266-1277.

70. Zaidi, S.K., Sullivan, A.J., Medina, R., Ito, Y., van Wijnen, A.J., Stein, J.L., Lian, J.B., and Stein, G.S. (2004) Tyrosine phosphorylation controls Runx2-mediated subnuclear targeting of YAP to repress transcription. EMBO J. 23, 790-799.

71. Pei, Y., Harvey, A., Yu, X.P., Chandrasekhar, S., and Thirunavukkarasu, K. (2006) Differential regulation of cytokine-induced MMP-1 and MMP-13 expression by p38 kinase inhibitors in human chondrosarcoma cells: potential role of Runx2 in mediating p38 effects. Osteoarthritis Cartilage 14, 749-758.

72. Xiao, G., Gopalakrishnan, R., Jiang, D., Reith, E., Benson, M.D., and Franceschi, R.T. (2002) Bone morphogenetic proteins, extracellular matrix, and mitogen-activated protein kinase signaling pathways are required for osteoblastspecific gene expression and differentiation in MC3T3-E1 cells. J. Bone Miner. Res. 17, 101-110.

73. Xiao, G., Jiang, D., Thomas, P., Benson, M.D., Guan, K., Karsenty, G., and Franceschi, R.T. (2000) MAPK pathways activate and phosphorylate the osteoblast-specific transcription factor, Cbfa1. J. Biol. Chem. 275, 4453-4459.

74. Franceschi, R.T., and Xiao, G. (2003) Regulation of the osteoblast-specific transcription factor, Runx2: responsiveness to multiple signal transduction pathways. J. Cell. Biochem. 88, 446-454.

75. Liao, Q.C., Xiao, Z.S., Qin, Y.F., and Zhou, H.H. (2007) Genistein stimulates osteoblastic differentiation via p38 MAPK-Cbfa1 pathway in bone marrow culture. Acta Pharmacol. Sin. 28, 1597-1602. 
76. Xiao, G., Jiang, D., Gopalakrishnan, R., and Franceschi, R.T. (2002) Fibroblast growth factor 2 induction of the osteocalcin gene requires MAPK activity and phosphorylation of the osteoblast transcription factor, Cbfa1/Runx2. $J$. Biol. Chem. 277, 36181-36187.

77. Chikuda, H., Kugimiya, F., Hoshi, K., Ikeda, T., Ogasawara, T., Shimoaka, T., Kawano, H., Kamekura, S., Tsuchida, A., Yokoi, N., Nakamura, K., Komeda, K., Chung, U.I., and Kawaguchi, H. (2004) Cyclic GMP-dependent protein kinase II is a molecular switch from proliferation to hypertrophic differentiation of chondrocytes. Genes Dev. 18, 2418-2429.

78. Schlossmann, J., Feil, R., and Hofmann, F. (2005) Insights into cGMP signalling derived from cGMP kinase knockout mice. Front. Biosci. 10, 1279-1289.

79. Boileau, C., Martel-Pelletier, J., Brunet, J., Tardif, G., Schrier, D., Flory, C., El-Kattan, A., Boily, M., and Pelletier, J.P. (2005) Oral treatment with PD-0200347, an alpha2delta ligand, reduces the development of experimental osteoarthritis by inhibiting metalloproteinases and inducible nitric oxide synthase gene expression and synthesis in cartilage chondrocytes. Arthritis Rheum. 52, 488-500.

80. Manacu, C.A., Martel-Pelletier, J., Roy-Beaudry, M., Pelletier, J.P., Fernandes, J.C., Shipkolye, F.S., Mitrovic, D.R., and Moldovan, F. (2005) Endothelin-1 in osteoarthritic chondrocytes triggers nitric oxide production and upregulates collagenase production. Arthritis Res. Ther. 7, R324-332.

81. Lin, S.K., Kok, S.H., Lin, L.D., Wang, C.C., Kuo, M.Y., Lin, C.T., Hsiao, M., and Hong, C.Y. (2007) Nitric oxide promotes the progression of periapical lesion via inducing macrophage and osteoblast apoptosis. Oral Microbiol. Immunol. 22, 24-29.

82. Olivier, S., Fillet, M., Malaise, M., Piette, J., Bours, V., Merville, M.P., and Franchimont, N. (2005) Sodium nitroprusside-induced osteoblast apoptosis is mediated by long chain ceramide and is decreased by raloxifene. Biochem. Pharmacol. 69, 891-901.

83. Ho, W.P., Chen, T.L., Chiu, W.T., Tai, Y.T., and Chen, R.M. (2005) Nitric oxide induces osteoblast apoptosis through a mitochondria-dependent pathway. Ann. N. Y. Acad. Sci. 1042, 460-470.

84. Chen, R.M., Chen, T.L., Chiu, W.T., and Chang, C.C. (2005) Molecular mechanism of nitric oxide-induced osteoblast apoptosis. J. Orthop. Res. 23, 462-468.

85. Lin, S.K., Kok, S.H., Kuo, M.Y., Lee, M.S., Wang, C.C., Lan, W.H., Hsiao, M., Goldring, S.R., and Hong, C.Y. (2003) Nitric oxide promotes infectious bone resorption by enhancing cytokine-stimulated interstitial collagenase synthesis in osteoblasts. J. Bone Miner. Res. 18, 39-46.

86. Chang, C.C., Liao, Y.S., Lin, Y.L., and Chen, R.M. (2006) Nitric oxide protects osteoblasts from oxidative stressinduced apoptotic insults via a mitochondria-dependent mechanism. J. Orthop. Res. 24, 1917-1925.

87. Ho, W.P., Chan, W.P., Hsieh, M.S., and Chen, R.M. (2009) Runx2-mediated bcl-2 gene expression contributes to nitric oxide protection against hydrogen peroxide-induced osteoblast apoptosis. J. Cell. Biochem. 108, 1084-1093.

88. Chen, R.M., Liu, H.C., Lin, Y.L., Jean, W.C., Chen, J.S., and Wang, J.H. (2002) Nitric oxide induces osteoblast apoptosis through the de novo synthesis of Bax protein. J. Orthop. Res. 20, 295-302.

89. Lago, R., Gomez, R., Otero, M., Lago, F., Gallego, R., Dieguez, C., Gomez-Reino, J.J., and Gualillo, O. (2008) A new player in cartilage homeostasis: adiponectin induces nitric oxide synthase type II and pro-inflammatory cytokines in chondrocytes. Osteoarthritis Cartilage 16, 1101-1109.

90. Hirai, Y., Migita, K., Honda, S., Ueki, Y., Yamasaki, S., Urayama, S., Kamachi, M., Kawakami, A., Ida, H., Kita, M., Fukuda, T., Shibatomi, K., Kawabe, Y., Aoyagi, T., and Eguchi, K. (2001) Effects of nitric oxide on matrix metalloproteinase-2 production by rheumatoid synovial cells. Life Sci. 68, 913-920.

91. Kumar, D.A., Raju, K.V., Settu, K., Kumanan, K., and Puvanakrishnan, R. (2006) Effect of a derivatized tetrapeptide from lactoferrin on nitric oxide mediated matrix metalloproteinase-2 production by synovial fibroblasts in collageninduced arthritis in rats. Peptides 27, 1434-1442.

92. Aupperle, K.R., Boyle, D.L., Hendrix, M., Seftor, E.A., Zvaifler, N.J., Barbosa, M., and Firestein, G.S. (1998) Regulation of synoviocyte proliferation, apoptosis, and invasion by the p53 tumor suppressor gene. Am. J. Pathol. 152, 1091-1098.

93. Chen, Q., Casali, B., Pattacini, L., Boiardi, L., and Salvarani, C. (2006) Tumor necrosis factor-alpha protects synovial cells from nitric oxide induced apoptosis through phosphoinositide 3-kinase Akt signal transduction. J. Rheumatol. 33, 1061-1068.

94. van't Hof, R.J., Hocking, L., Wright, P.K., and Ralston, S.H. (2000) Nitric oxide is a mediator of apoptosis in the rheumatoid joint. Rheumatology (Oxford) 39, 1004-1008.

95. Heale, C.E., Fahraeus-Van Ree, G.E., Rahman, P., and Richardson, V.J. (2007) Progressive and concordant expression of PKC-eta and iNOS phenotypes in monocytes from patients with rheumatoid arthritis: association with disease severity. J. Histochem. Cytochem. 55, 495-503.

96. Cope, A.P. (2008) T cells in rheumatoid arthritis. Arthritis Res. Ther. 10(Suppl 1), S1.

97. Nagy, G., Clark, J.M., Buzas, E., Gorman, C., Pasztoi, M., Koncz, A., Falus, A., and Cope, A.P. (2008) Nitric oxide production of T lymphocytes is increased in rheumatoid arthritis. Immunol. Lett. 118, 55-58.

98. Gonzalez-Gay, M.A., Llorca, J., Sanchez, E., Lopez-Nevot, M.A., Amoli, M.M., Garcia-Porrua, C., Ollier, W.E., and Martin, J. (2004) Inducible but not endothelial nitric oxide synthase polymorphism is associated with susceptibility to rheumatoid arthritis in northwest Spain. Rheumatology (Oxford) 43, 1182-1185. 
99. Varade, J., Lamas, J.R., Fernandez-Arquero, M., Jover, J.A., de la Concha, E.G., Martinez, A., Fernandez-Gutierrez, B., and Urcelay, E. (2009) NO role of NOS2A susceptibility polymorphisms in rheumatoid arthritis. Nitric Oxide 21, 171-174.

100. Vazgiourakis, V., Sidiropoulos, P., Bertsias, G., Koutsounaki, E., Fragouli, E., Raptopoulou, A., Kritikos, H., Boumpas, D.T., and Goulielmos, G.N. (2007) Association of the nitric oxide synthase (eNOS) gene polymorphism with increased risk for both lupus glomerulonephritis and rheumatoid arthritis in a single genetically homogeneous population. Lupus 16, 867-874.

101. Brenol, C.V., Chies, J.A., Brenol, J.C., Monticielo, O.A., Franciscatto, P., Birriel, F., Neves, A.G., and Xavier, R.M. (2009) Endothelial nitric oxide synthase T-786C polymorphism in rheumatoid arthritis: association with extraarticular manifestations. Clin. Rheumatol. 28, 201-205.

102. Gonzalez-Gay, M.A., Llorca, J., Palomino-Morales, R., Gomez-Acebo, I., Gonzalez-Juanatey, C., and Martin, J. (2009) Influence of nitric oxide synthase gene polymorphisms on the risk of cardiovascular events in rheumatoid arthritis. Clin. Exp. Rheumatol. 27, 116-119.

\section{This article should be cited as follows:}

Saura, M., Tarin, C., and Zaragoza, C. (2010) Recent insights into the implication of nitric oxide in osteoblast differentiation and proliferation during bone development. TheScientificWorldJOURNAL 10, 624-632. DOI 10.1100/tsw.2010.58. 

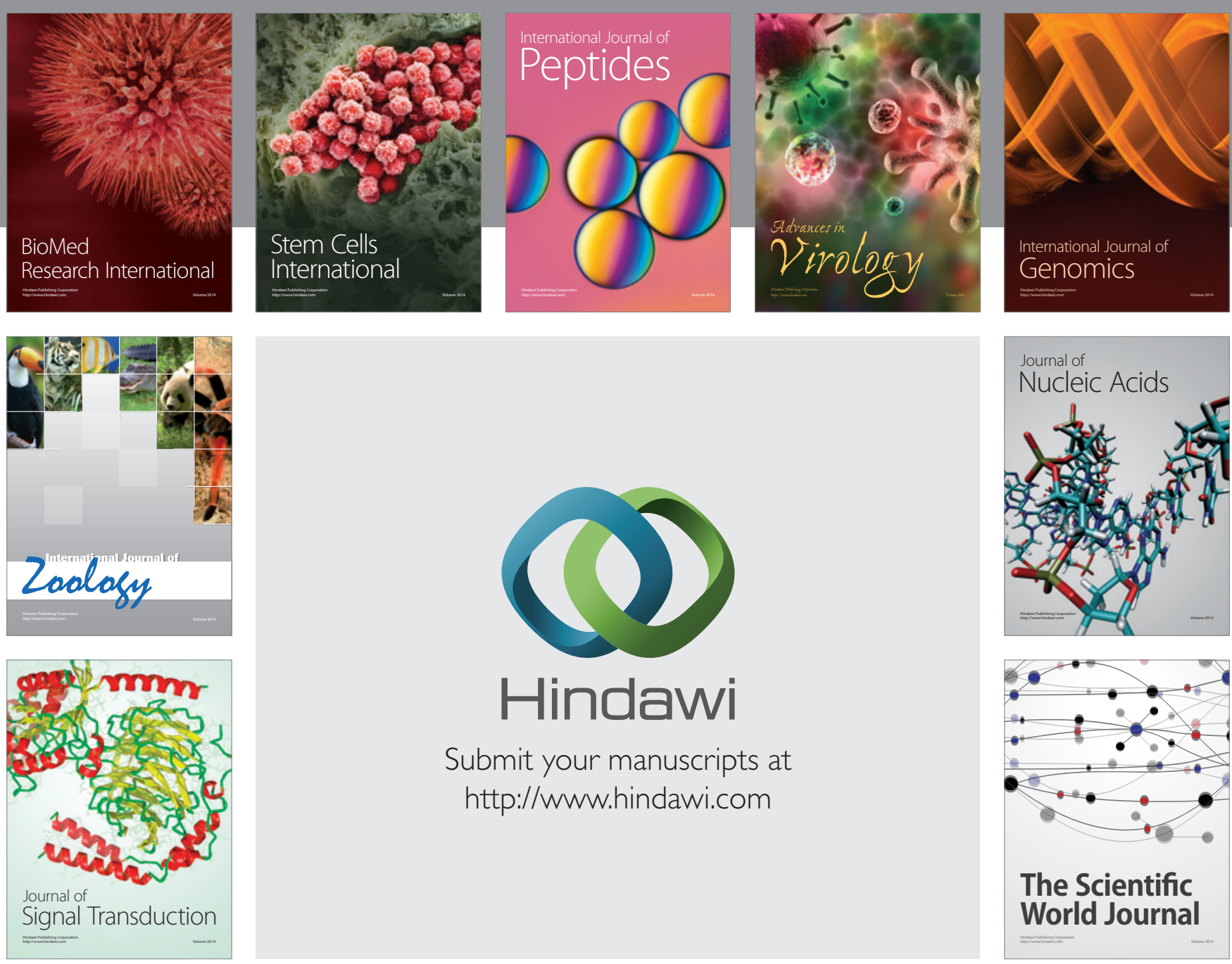

Submit your manuscripts at

http://www.hindawi.com
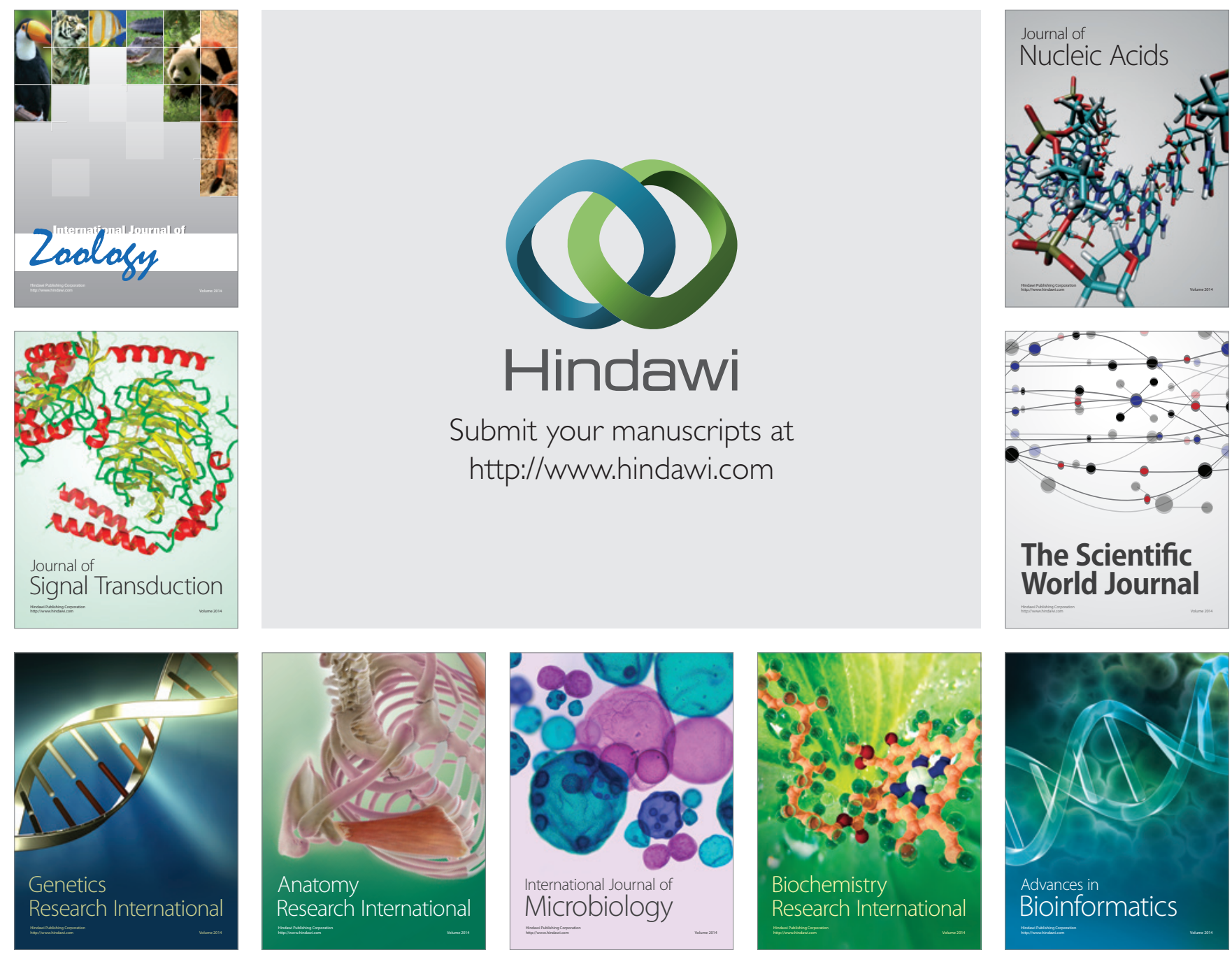

The Scientific World Journal
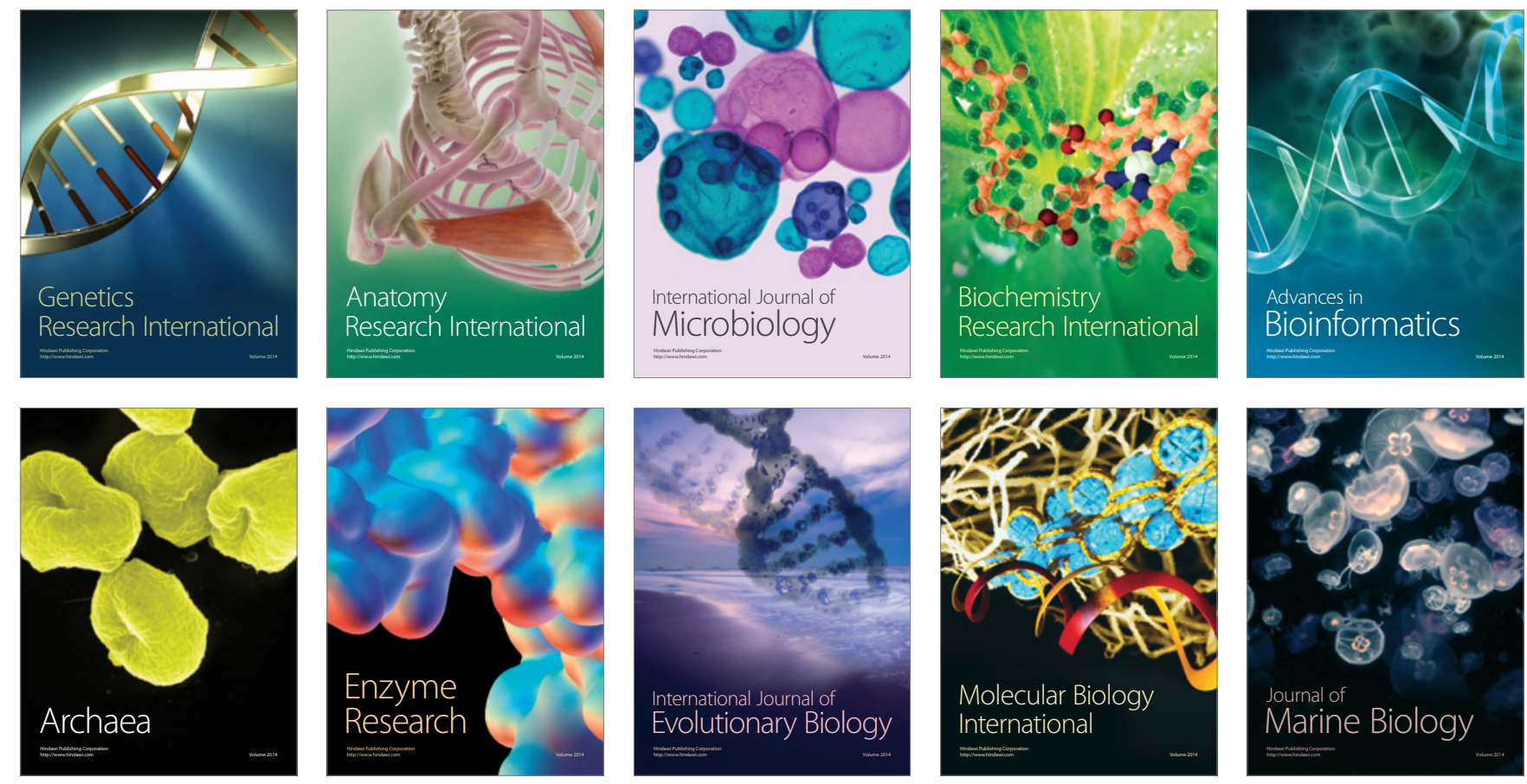